\title{
Complete mitochondrial genome sequences of two parasitic/commensal nemerteans, Gononemertes parasita and Nemertopsis tetraclitophila (Nemertea: Hoplonemertea)
}

Wen-Yan Sun ${ }^{1}$, Dong-Li Xu' ${ }^{1}$, Hai-Xia Chen ${ }^{1,2}$, Wei Shi ${ }^{3}$, Per Sundberg ${ }^{2}$, Malin Strand ${ }^{4}$ and Shi-Chun Sun ${ }^{{ }^{*}}$

\begin{abstract}
Background: Most nemerteans (phylum Nemertea) are free-living, but about 50 species are known to be firmly associated with other marine invertebrates. For example, Gononemertes parasita is associated with ascidians, and Nemertopsis tetraclitophila with barnacles. There are 12 complete or near-complete mitochondrial genome (mitogenome) sequences of nemerteans available in GenBank, but no mitogenomes of none free-living nemerteans have been determined so far. In the present paper complete mitogenomes of the above two parasitic/commensal nemerteans are reported.
\end{abstract}

Methods: The complete mitochondrial genomes (mitogenome) of G. parasita and N. tetraclitophila were amplified by conventional and long PCR. Phylogenetic analyses of maximum likelihood (ML) and Bayesian inference (BI) were performed with both concatenated nucleotide and amino acid sequences.

Results: Complete mitogenomes of G. parasita and N. tetraclitophila are 14742 bp and 14597 bp in size, respectively, which are within the range of published Hoplonemertea mitogenomes. Their gene orders are identical to that of published Hoplonemertea mitogenomes, but different from those of Palaeo- and Heteronemertea species. All the coding genes, as well as major non-coding regions (mNCRs), are AT rich, which is especially pronounced at the third codon position. The AT/GC skew pattern of the coding strand is the same among nemertean mitogenomes, but is variable in the $\mathrm{mNCRs}$. Some slight differences are found between mitogenomes of the present species and other hoplonemerteans: in G. parasita the $\mathrm{mNCR}$ is biased toward T and C (contrary to other hoplonemerteans) and the rrnS gene has a unique 58-bp insertion at the $5^{\prime}$ end; in N. tetraclitophila the nad3 gene starts with the ATT codon (ATG in other hoplonemerteans). Phylogenetic analyses of the nucleotide and amino acid datasets show early divergent positions of G. parasita and N. tetraclitophila within the analyzed Distromatonemertea species, and provide strong support for the close relationship between Hoplonemertea and Heteronemertea.

Conclusion: Gene order is highly conserved within the order Monostilifera, particularly within the Distromatonemertea, and the special lifestyle of G. parasita and N. tetraclitophila does not bring significant variations to the overall structures of their mitogenomes in comparison with free-living hoplonemerteans.

Keywords: Nemertea, Gononemertes parasita, Nemertopsis tetraclitophila, Parasitic/Commensal, Mitochondrial genome, Phylogeny

\footnotetext{
* Correspondence: sunsc@ouc.edu.cn

${ }^{1}$ Institute of Evolution \& Marine Biodiversity, Ocean University of China, 5

Yushan Road, Qingdao 266003, China

Full list of author information is available at the end of the article
} 


\section{Background}

The phylum Nemertea (ribbon worm) includes about 1280 named species [1]. Most of them are free-living in marine, freshwater and terrestrial habitats, but there are about 50 species reported to be associated with other animals; host organisms include poriferans, cnidarians, bivalves, echiurans, crustaceans, echinoderms and ascidians. The position of Nemertea among metazoans was traditionally considered to be close to the acoelomate Platyhelminthes, but comparative ultrastructure studies and molecular phylogenetic analyses during recent decades have supported it to be a member of the Lophotrochozoa [2-6]. The phylogenetic relationship of the phylum is still unsettled in parts, and conclusions may be dependent on different markers and analytical methods [7-9]. A recent analysis based on four nuclear and two mitochondrial loci further suggested that an expanded taxon sampling at family and generic level was required for getting a better understanding of nemertean affinities [9].

To date, there are 12 complete or near-complete nemertean mitogenome sequences available in GenBank. From these, we can infer some interesting patterns in terms of genome organization. For instance, Palaeonemertea and Heteronemertea bear larger mitogenomes than the more recently diverged hoplonemertean taxon Distromatonemertea. The gene arrangement within the phylum is not conserved, but generally stable within each of the three major groups (Palaeo-, Hetero- and Hoplonemertea). Nevertheless, a fuller understanding of the evolutionary patterns of nemertean mitogenome evolution requires denser taxon sampling, particularly of taxa that have adopted unusual lifestyles, such as Malacobdella and Carcinonemertes. In the present study, we determined the first complete mitogenome sequences of two parasitic/commensal nemerteans, Gononemertes parasita Bergendal, 1900 and Nemertopsis tetraclitophila Gibson, 1990, which taxonomically belong to Monostilifera (a group that contains most known symbiotic nemerteans). G. parasita lives in the branchial chamber of some ascidians in European waters [10], whereas N. tetraclitophila has been recorded from the mantle cavity of the balanomorph barnacle Tetraclita squamosa (Bruguiére, 1789) in Hong Kong, China [11]. Worms of both species seem to be firmly associated with a host, and possess some adaptive features that might be related to none free-living lifestyle, e.g., the greater number of gonads than most freeliving monostiliferans; the absence of a proboscis apparatus (G. parasita) [11,12]. Mostly based on reproductive adaptations, Roe has argued that G. parasita and another Nemertopis species living in barnacles (Nemertopis quadripunctata (Quoy \& Gaimard, 1833), which feeds on the eggs of the barnacles and possibly on the barnacles themselves) should be regarded as parasites [13]. However, the ecology, particularly the feeding biology, of G. parasita and $N$. tetraclitophila has not been well understood.
Therefore, the two species are cautiously mentioned as "parasitic/commensal" in the present paper.

\section{Methods}

\section{Specimens and DNA extraction}

Gononemertes parasita was collected from the branchial chamber of the sea squirt Ascidia obliqua Alder, 1863 near Tjärnö, Sweden. Nemertopsis tetraclitophila was collected from the mantle cavity of the barnacle Tetraclita squamosa in Shenzhen, China. For either species, total DNA was extracted from a single specimen using the Genomic DNA Extraction Kit (OMEGA) following the manufacturer's instructions and stored at $-20^{\circ} \mathrm{C}$.

\section{PCR amplification and sequencing}

Small fragments such as coxl, rrnS-rrnL, cob and cox3 were amplified with universal primers, and then specific primers were designed for the amplification of long fragments (Additional file 1: Table S1). All PCR reactions were carried out in a reaction volume of $25 \mu$ l containing 12.5 $\mu \mathrm{l}$ Premix Taq (LA version 2.0) (TaKaRa Clone Tech), $0.5 \mu \mathrm{l}$ each primer, $0.5 \mu \mathrm{l}$ DNA template and $11 \mu \mathrm{l}$ distilled $\mathrm{H}_{2} \mathrm{O}$. The PCR amplifications were performed under the following conditions: $4 \mathrm{~min}$ at $94^{\circ} \mathrm{C}$, followed by 35 cycles of $30 \mathrm{~s}$ at $94^{\circ} \mathrm{C}, 30 \mathrm{~s}$ at $48-50^{\circ} \mathrm{C}$ (according to primers), $1-$ $10 \mathrm{~min}$ (according to the length of products) at $72^{\circ} \mathrm{C}$, followed by a $10 \mathrm{~min}$ elongation. The PCR products were separated by agarose gel electrophoresis and purified using DNA gel extraction kit (OMEGA). The purified PCR products were ligated into $p E A S Y$-T1 vector (Transgen, China) and sequenced by primer walking on an ABI 3730 Sequencer.

\section{Genome assembly and annotation}

All the sequences were compared with other nemerteans to prevent contaminations from a host or bacteria. The obtained fragments of mitogenomes were assembled with Codoncode Aligner 5.0.1. Identification of protein-coding genes and rRNA genes was performed by BLAST searches (http://www.ncbi.nlm.nih.gov/BLAST) and by alignment to known hoplonemertean mitogenomes. Most tRNA genes were identified by tRNAscan-SE 1.21 [14], and additional tRNA genes were inferred with RNAfold [15]. The mitogenome was visualized using CGView [16]. The nucleotide composition and codon usage were calculated with DAMBE 5 [17]. Multiple alignments of genes were generated by Clustal X [18] with default settings and amino acid translation was carried out using MEGA 5.0 [19]. The full mitogenome sequences of Gononemertes parasita [KF572481] and Nemertopsis tetraclitophila [KF572482] were submitted to GenBank and compared with Cephalothrix hongkongiensis [NC_012821], Cephalothrix sp. [NC_014869], Iwatanemertes piperata [KF719984], Lineus viridis [NC_012889], Lineus alborostratus [NC_018356], 
Nectonemertes cf. mirabilis [NC_017874], Amphiporus formidabilis [KC710979], Emplectonema gracile [NC_016952], Paranemertes cf. peregrina [NC_014865], Zygeupolia rubens [NC_017877], Prosadenoporus spectaculum [KC710980] and Nipponnemertes punctatula [KC710981].

\section{Phylogenetic analysis}

Phylogenetic analyses of the 14 available nemertean mitogenomes were carried out as follows: i) nucleotide-level analysis of protein-coding genes, with 3rd codon position removed; ii) nucleotide-level analysis of protein-coding genes, with 3rd codon position removed, rRNA and tRNA genes, iii) amino acid-level analysis of protein-coding genes. The saturation test was carried out based on the transition and transversion substitutions vs. the Tamura-Nei (TN93) distance of three codon positions by DAMBE 5 [17], and the third codon position which tended to be saturated (the transition and transversion substitution values do not increase as the genetic distance increase) was not used in phylogenetic analyses. The outgroups Katharina tunicata [NC_001636] and Terebratulina retusa [NC_000941] were selected based on their close relationships with Nemertea in previous studies [20,21]. All datasets were aligned with Clustal X with default settings [18]. Poorly aligned positions were excluded using Gblocks Version 0.91b [22] allowing less strict flanking positions and other default parameters. For nucleotide sequences MODELTEST [23] and MRMODELTEST [24], and for amino acid sequences ProtTest 2.4 [25] were used to select the best-fit substitution models (the model parameters were estimated when the concatenated nucleotides/amino acids were treated as a single partition). Based on the Akaike Information Criterion (AIC), the best-fit model for nucleotides was the $\mathrm{GTR}+\mathrm{I}+\mathrm{G}$ and for amino acid sequences was the MtRev $+G+F$. The ML analysis was performed with PHYML 3.0 program (http://www.atgc-montpellier.fr/ phyml/) [26] with 100 bootstrap replicates. Bayesian inference was conducted using MrBayes version 3.1.2 [27]. Four Monte Carlo Markov chains (MCMC) were run for 1,000,000 generations, sampling every 100 generations. The first 2500 trees were omitted as burn-in. To ensure convergence, the run was not ended until the average standard deviation of split frequencies reached $<0.01$ and the PSRF values were close to 1 for all parameters. To investigate the contribution of different genes, the nucleotide data matrix containing the 1st and 2nd codon positions, rRNA and tRNA sequences was subjected to a heuristic parsimony analysis (i.e. hsearch addseq $=$ random nreps $=1000$ swap $=$ TBR multrees $=$ yes start $=$ stepwise) in PAUP $* 4.0$ [28] and TreeRot.v3 [29] was used to calculate the partitioned Bremer support (PBS) values $[30,31]$ of each gene partition on the tree nodes.

\section{Results and discussion}

\section{Genome organization and base composition}

As observed in the previously determined Hoplonemertea mitogenomes, both of the present mitogenomes also include 13 protein-coding genes, two rRNAs and 22 tRNAs genes, all encoded on the coding strand except for trnP and trnT (Figure 1 and Table 1). The gene orders are identical to previously published hoplonemertean mitogenomes without exceptions. There are several overlaps throughout the two mitogenomes, for example, the 8-bp overlaps between nad6 and cob (Table 1).

The nucleotide composition of the coding strand is biased toward $\mathrm{T}$ and $\mathrm{A}$ in these two mitogenomes, as is the case in most metazoan mitogenomes [32]. The $\mathrm{A}+\mathrm{T}$ content of the coding strands in G. parasita and N. tetraclitophila is $68.8 \%$ and $71.2 \%$ respectively, which falls within the range of the previously sequenced nemertean mitogenomes (from $64.7 \%$ in Lineus alborostratus to $75.7 \%$ in Cephalothrix sp.) (Table 2). The A+ T biased composition is particularly pronounced at the third codon position of the protein-coding genes $(75.4 \%$ and $82.5 \%$, respectively). The coding strands bear several poly-T stretches with the longest one being 20 Ts in G. parasita and 33 Ts in N. tetraclitophila, which have proved to be detrimental to PCR amplification [33,34]. Among lophotrochozoans, AT- and GC skews always show high interor intra-phylum variation, which might affect phylogenetic analyses [35]. The nucleotide skewness for the coding

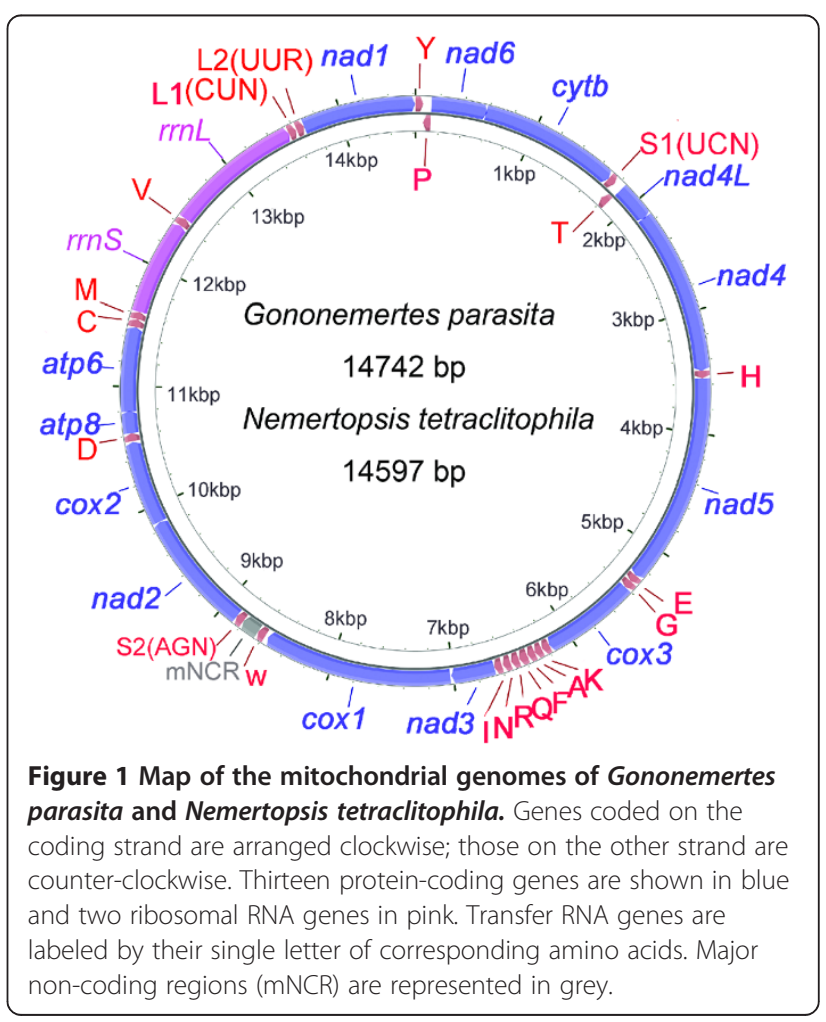


Table 1 The mitochondrial genome organization of Gononemertes parasita and Nemertopsis tetraclitophila

\begin{tabular}{|c|c|c|c|c|c|c|c|c|c|c|}
\hline \multirow[t]{2}{*}{ Genes } & \multicolumn{5}{|c|}{ Gononemertes parasita } & \multicolumn{5}{|c|}{ Nemertopsis tetraclitophila } \\
\hline & From $5^{\prime}$ to $3^{\prime}$ & Size (bp) & Start codon & Stop codon & 3' spacer & From $5^{\prime}$ to $3^{\prime}$ & Size (bp) & Start codon & Stop codon & 3' spacer \\
\hline $\operatorname{trn} Y$ & $1-66$ & 66 & & & 1 & $1-63$ & 63 & & & 9 \\
\hline $\operatorname{trn} P^{a}$ & $133-68$ & 66 & & & 3 & $138-73$ & 66 & & & 8 \\
\hline nad6 & $137-604$ & 468 & ATG & TAG & -8 & $147-605$ & 459 & ATG & TAG & -8 \\
\hline Cob & $597-1733$ & 1137 & ATG & TAA & 5 & $598-1734$ & 1137 & ATG & TAG & -1 \\
\hline $\operatorname{trnSi}(\mathrm{UCN})$ & $1739-1797$ & 59 & & & 0 & 1734-1798 & 65 & & & 0 \\
\hline $\operatorname{trn} T^{a}$ & $1862-1798$ & 65 & & & 4 & 1860-1799 & 62 & & & 2 \\
\hline $\operatorname{nad} 4 \mathrm{~L}$ & $1867-2169$ & 303 & GTG & TAA & -7 & $1863-2165$ & 303 & ATG & TAG & -11 \\
\hline nad4 & 2163-3497 & 1335 & ATG & TAG & 23 & $2155-3504$ & 1350 & ATG & TAA & 15 \\
\hline $\operatorname{trnH}$ & $3521-3590$ & 70 & & & 0 & $3520-3581$ & 62 & & & 0 \\
\hline nad5 & $3591-5324$ & 1734 & GTG & TAG & -10 & $3582-5304$ & 1723 & ATG & $\mathrm{T}$ & 0 \\
\hline $\operatorname{trn} E$ & $5315-5381$ & 67 & & & 6 & $5305-5368$ & 64 & & & 2 \\
\hline $\operatorname{trn} G$ & $5388-5451$ & 64 & & & 2 & $5371-5434$ & 64 & & & 1 \\
\hline $\cos 3$ & $5454-6233$ & 780 & ATG & TAG & 7 & $5436-6215$ & 780 & ATG & TAG & 5 \\
\hline $\operatorname{trnk}$ & 6241-6309 & 69 & & & 0 & $6221-6281$ & 61 & & & -1 \\
\hline $\operatorname{trn} A$ & $6310-6373$ & 64 & & & 0 & $6281-6344$ & 64 & & & 5 \\
\hline $\operatorname{trnF}$ & $6374-6439$ & 66 & & & 10 & $6350-6413$ & 64 & & & 9 \\
\hline $\operatorname{trn} Q$ & $6450-6518$ & 69 & & & 0 & $6423-6493$ & 71 & & & 3 \\
\hline $\operatorname{trn} R$ & 6519-6583 & 65 & & & 8 & $6497-6560$ & 64 & & & 2 \\
\hline $\operatorname{trn} N$ & $6592-6657$ & 66 & & & 7 & $6563-6626$ & 64 & & & 0 \\
\hline $\operatorname{trnl}$ & $6665-6729$ & 65 & & & 1 & $6627-6690$ & 64 & & & 7 \\
\hline nad3 & $6731-7084$ & 354 & ATG & TAA & 1 & $6698-7040$ & 343 & ATT & T & 0 \\
\hline $\cos 1$ & $7086-8621$ & 1536 & ATG & TAA & 28 & $7041-8576$ & 1536 & ATG & TAG & 33 \\
\hline $\operatorname{trn} W$ & $8650-8718$ & 69 & & & 0 & $8610-8676$ & 67 & & & 0 \\
\hline$m N C R^{b}$ & 8719-8838 & 120 & & & 0 & $8677-8813$ & 137 & & & 0 \\
\hline $\operatorname{trnS2}(A G N)$ & 8839-8905 & 67 & & & -1 & $8814-8880$ & 67 & & & 0 \\
\hline nad2 & 8905-9901 & 997 & GTG & T & 11 & 8881-9877 & 997 & ATG & $T$ & 0 \\
\hline $\cos 2$ & 9913-10596 & 684 & ATG & TAG & 7 & 9878-10564 & 687 & ATG & TAA & -2 \\
\hline $\operatorname{trn} D$ & 10604-10668 & 65 & & & 0 & 10563-10629 & 67 & & & 0 \\
\hline atp8 & 10669-10839 & 171 & GTG & TAG & 7 & 10630-10797 & 168 & GTG & TAG & 5 \\
\hline atp6 & $10847-11539$ & 693 & ATG & TAG & 6 & 10803-11489 & 687 & ATG & TAG & -2 \\
\hline $\operatorname{trn} C$ & $11546-11612$ & 67 & & & 0 & $11488-11548$ & 61 & & & 0 \\
\hline $\operatorname{trn} M$ & $11613-11676$ & 64 & & & 0 & 11549-11611 & 63 & & & 0 \\
\hline$r r n s$ & $11677-12513$ & 837 & & & 0 & $11612-12384$ & 773 & & & 0 \\
\hline $\operatorname{trn} V$ & $12514-12578$ & 65 & & & 0 & $12385-12450$ & 66 & & & 0 \\
\hline$r r n L$ & 12579-13686 & 1108 & & & 0 & $12451-13540$ & 1090 & & & 0 \\
\hline $\operatorname{trn} L 1(C \cup N)$ & $13687-13750$ & 64 & & & 5 & 13541-13606 & 66 & & & 4 \\
\hline $\operatorname{trn} L 2(U \cup R)$ & 13756-13818 & 63 & & & 0 & $13611-13673$ & 63 & & & 0 \\
\hline nad1 & 13819-14739 & 921 & GTG & TAA & 3 & 13674-14594 & 921 & GTG & TAG & 3 \\
\hline
\end{tabular}

athe genes coded on the opposite strand.

${ }^{\mathrm{b}} \mathrm{mNCR}$ represents the major non-coding region.

strands of $N$. tetraclitophila (AT-skew $=-0.41, \mathrm{GC}$-skew $=$ 0.34 ) and $G$. parasita (AT-skew $=-0.46, \mathrm{GC}$-skew $=0.28$ ) is biased toward T and G. A similar trend has been observed in other Nemertea mitogenomes (Figure 2): the negative AT-skew ranges from -0.46 (G. parasita) to -0.27 (Cephalothrix sp., C. hognkongiensis and L. alborostratus) and the GC-skew is always positive varying from 0.18 (Cephalothrix sp.) to 0.44 (N. punctatula). It is noteworthy 
Table 2 Nucleotide compositions of Gononemertes parasita (Gp) and Nemertopsis tetraclitophila (Nt) mitogenomes

\begin{tabular}{|c|c|c|c|c|c|c|c|c|c|c|c|c|}
\hline \multirow[t]{2}{*}{ Feature } & \multicolumn{2}{|c|}{ Length (bp) } & \multicolumn{2}{|c|}{ A (\%) } & \multicolumn{2}{|c|}{ C (\%) } & \multicolumn{2}{|c|}{ G (\%) } & \multicolumn{2}{|c|}{$\mathrm{T}(\%)$} & \multicolumn{2}{|c|}{$A+T(\%)$} \\
\hline & Gp & $\mathrm{Nt}$ & $\mathrm{Gp}$ & $\mathrm{Nt}$ & $\mathrm{Gp}$ & $\mathrm{Nt}$ & Gp & $\mathrm{Nt}$ & Gp & $\mathrm{Nt}$ & $\mathrm{Gp}$ & $\mathrm{Nt}$ \\
\hline Coding strand & 14742 & 14597 & 18.6 & 21.1 & 11.2 & 9.5 & 20.0 & 19.3 & 50.3 & 50.0 & 68.8 & 71.2 \\
\hline Protein-coding genes ${ }^{a}$ & 11076 & 11058 & 15.8 & 18.1 & 11.5 & 9.6 & 20.4 & 19.6 & 52.3 & 52.8 & 68.1 & 70.9 \\
\hline 1st codon position & 3692 & 3686 & 18.0 & 20.2 & 12.6 & 11.5 & 25.2 & 25.0 & 44.3 & 43.2 & 62.2 & 63.5 \\
\hline 2nd codon position & 3692 & 3686 & 14.8 & 16.1 & 16.1 & 15.2 & 17.4 & 18.2 & 51.8 & 50.5 & 66.6 & 66.6 \\
\hline 3rd codon position & 3692 & 3686 & 14.6 & 17.9 & 6.0 & 2.1 & 18.6 & 15.4 & 60.8 & 64.6 & 75.4 & 82.5 \\
\hline tRNA genes & 1445 & 1418 & 29.4 & 32.0 & 10.2 & 10.4 & 20.8 & 19.7 & 39.6 & 37.9 & 69.0 & 70.0 \\
\hline rrnL gene & 1108 & 1090 & 26.7 & 28.6 & 9.8 & 8.9 & 17.5 & 17.6 & 45.9 & 45.0 & 72.7 & 73.6 \\
\hline rrns gene & 837 & 773 & 24.9 & 30.0 & 10.0 & 9.2 & 19.1 & 18.0 & 46.0 & 42.8 & 70.9 & 72.8 \\
\hline $\mathrm{mNCR}$ & 120 & 137 & 30.0 & 43.1 & 19.2 & 4.4 & 10.0 & 21.9 & 40.8 & 30.7 & 70.8 & 73.7 \\
\hline
\end{tabular}

a excluding stop codons.

that the nucleotide skews of the mNCRs are different among species (Figure 2), which reflects the relatively higher variability of $\mathrm{mNCR}$. The $\mathrm{mNCR}$ of $\mathrm{G}$. parasita is biased toward $\mathrm{T}$ and $\mathrm{C}$, which is contrary to other hoplonemerteans.

\section{Protein-coding genes}

The canonical start codons ATG and GTG are used in most protein-coding genes of the G. parasita and N. tetraclitophila mitogenomes. An exceptional case is the nad3 gene of $N$. tetraclitophila, which was inferred to be initiated by the ATT codon (Table 1), and its length (343 bp) is shorter than that of other Monostilifera species (354 bp). Nonstandard initiation codons were also inferred in previously sequenced nemertean mitogenomes, e.g., the $\operatorname{cox} 1$ (TCT) of Cephalothrix sp. and C. hongkongiensis. The majority of the protein-coding genes appear to use the stop codons TAA or TAG, except that the nad5, $n a d 3$ and nad2 genes in $N$. tetraclitophila and the nad2 gene in G. parasita use a single $\mathrm{T}$ as the termination codon, most of which are adjacent to a protein-coding gene and occasionally a tRNA gene (Table 1). The incomplete termination codon $\mathrm{T}$ has been proposed to be converted into the complete stop codon TAA through polyadenylation during posttranscriptional mRNA processing [36]. The overall length of protein-coding genes in the known nemertean mitogenomes varies from 11066 to $11268 \mathrm{bp}$. The protein-coding genes in seven Monostilifera mitogenomes

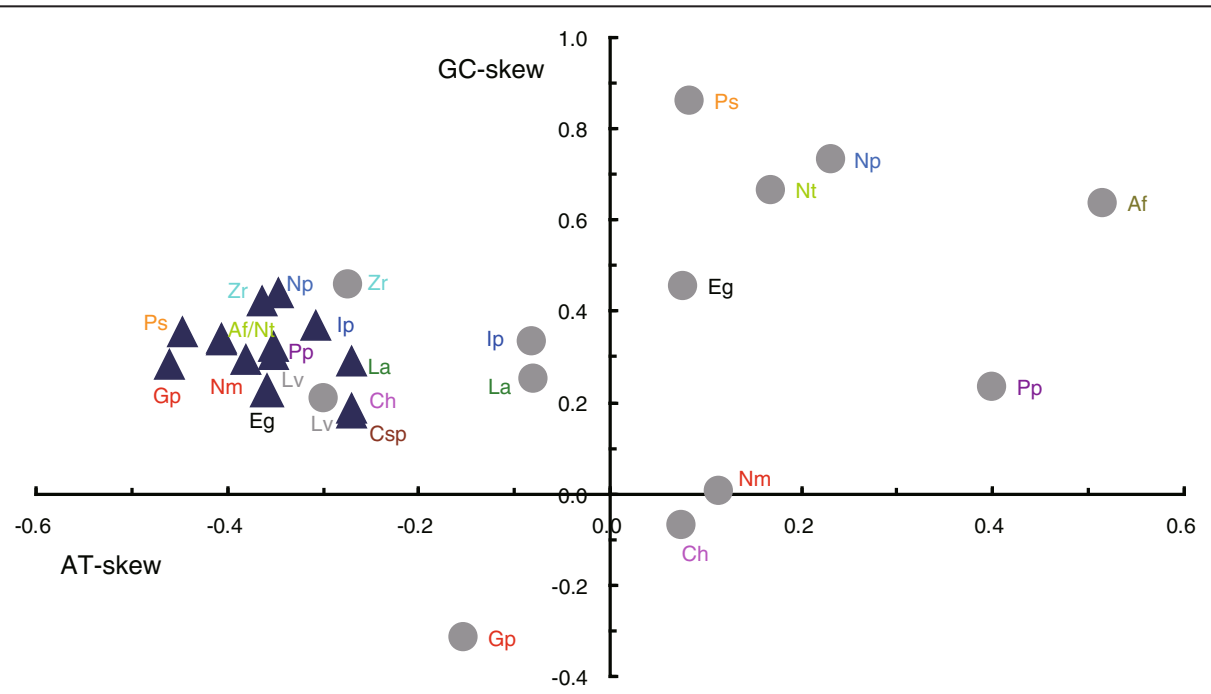

Figure 2 Scatter plot of AT- and GC-skews in 14 nemertean species. Values were calculated for the coding strand of the overall mitogenome sequences $(\boldsymbol{\Lambda})$ and the major non-coding region (Cephalothrix sp. not included because the major non-coding region of this species is incomplete) $(\bullet)$. AT-skew $=(\mathrm{A}-\mathrm{T}) /(\mathrm{A}+\mathrm{T})$; $\mathrm{GC}$-skew $=(\mathrm{G}-\mathrm{C}) /(\mathrm{G}+\mathrm{C})$. Af = Amphiporus formidabilis, $\mathrm{Ch}=$ Cephalothrix hongkongiensis, $\mathrm{Csp}=$ Cephalothrix sp., Eg = Emplectonema gracile, I $\mathrm{p}=$ Iwatanemertes piperata, $\mathrm{Gp}=$ Gononemertes parasita, $\mathrm{Lv}=$ Lineus viridis, La $=$ Lineus alborostratus, $\mathrm{Nt}=$ Nemertopsis tetraclitophila, $\mathrm{Np}=$ Nipponnemertes punctatula, $\mathrm{Nm}=$ Nectonemertes cf. mirabilis, $\mathrm{Ps}=$ Prosadenoporus spectaculum, $\mathrm{Pp}=$ Paranemertes cf. peregrina, $\mathrm{Zr}=$ Zygeupolia rubens. 
are shorter than that in the other nemerteans (Figure 3A). The two present mitogenomes do not exhibit apparent length change compared to other hoplonemertean mitogenomes, unlike in some parasitic insects whose proteincoding gene sizes are significantly smaller than those of free-living ones [37].

The overall nucleotide composition of 13 proteincoding genes in G. parasita and N. tetraclitophila mitogenomes are AT biased (68.1\% and 70.9\%, respectively). For both species, the third codon position has a considerably higher AT content ( $75.4 \%$ and $82.5 \%$, respectively) than the first and second codon positions and the lowest content of $\mathrm{C}$ (Table 2). According to the analysis of relative synonymous codon usage (RSCU), the two- and fourfold degenerate codons prefer the one ending with $\mathrm{T}$ (Additional file 2: Table S2), for example, GCT (2.811) is more frequently used than the other three codons $(0.297$ 0.486) for Ala. Corresponding to the high percentage of $\mathrm{T}$ in both mitogenomes, the most frequently used codon is TTT (17.6\% and $16.3 \%$, respectively), and Phe is the most frequently used amino acid (19.2\% and $16.8 \%$, respectively) (Additional file 2: Table S2). The other preferred amino acids in both species are Leu, Val, Gly and Ser, all of which might be associated with transmembrane functions. Similar codon usage and amino acid composition patterns have been observed in previously sequenced Nemertea mitogenomes [38].

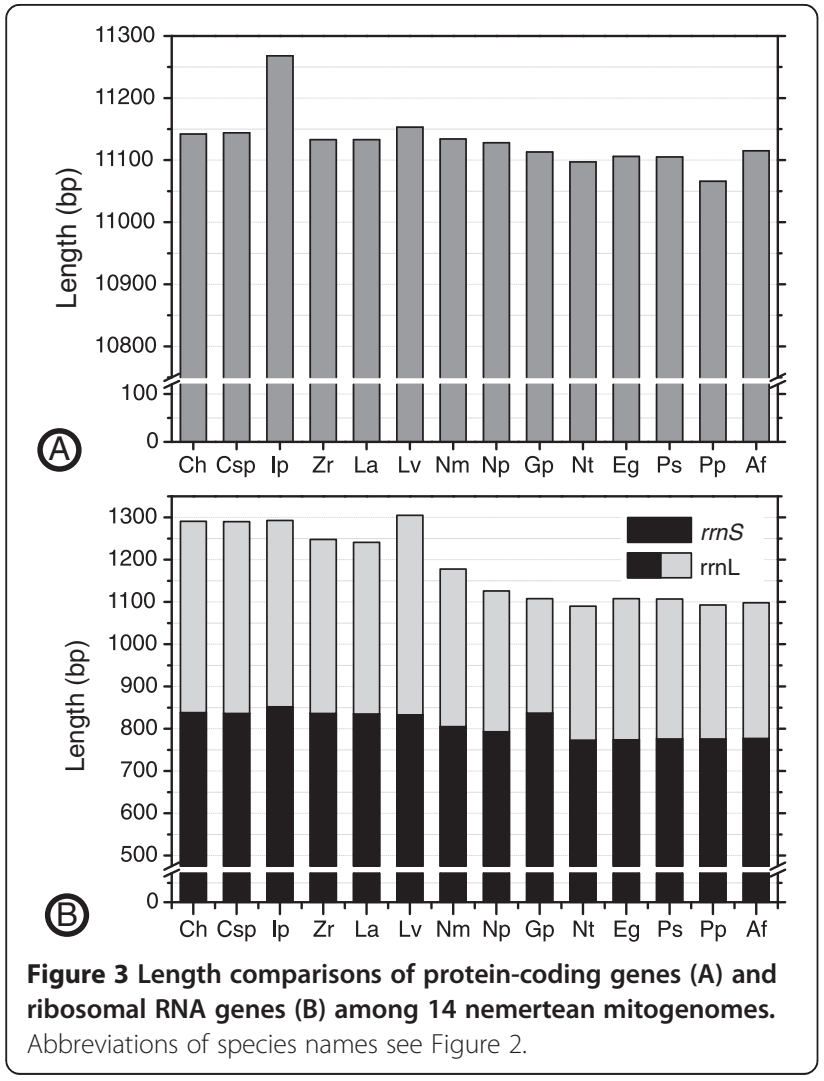

\section{Ribosomal and transfer RNA genes}

The ribosomal RNA genes ( $r r n L$ and $r r n S$ ) are located at the same location as in other nemertean mitogenomes, separated by $\operatorname{trn} V$. The $r r n L$ gene is 1,108 bp in G. parasita and 1,090 bp in N. tetraclitophila, and the A + T contents are $72.7 \%$ and $73.6 \%$, respectively. The $r r n S$ gene is $837 \mathrm{bp}$ and $773 \mathrm{bp}$, and the $\mathrm{A}+\mathrm{T}$ content is $70.9 \%$ and $72.8 \%$, respectively (Table 2 ). At the $5^{\prime}$ end of $r r n S$ gene in G. parasita, there is a region of 58 bp (TGTTTATTGG TATATTTTGATAAGTACTTTTAGTTTTATTCTATTT TTTTTCTTGTTT), which can neither be aligned with other nemertean $r r n S$ sequences nor does it show any similarity with any remaining parts of the mitogenome, making the $r r n S$ gene in G. parasita the longest among enoplan mitogenomes (Figure 3B). This insertion is also one major reason that G. parasita bears the largest mitogenome within Distromatonemertea. Except for $r r n S$ of $G$. parasita, the rRNA genes of monostiferans are apparently shorter than that of other nemerteans (Figure 3B).

$\mathrm{A}+\mathrm{T}$ contents in the tRNA genes is slightly lower than in the remainder of the mitogenomes. The anticodons of 22 tRNAs in both mitogenomes are the same as in other hoplonemerteans. All tRNA genes can be folded into conventional cloverleaf-like structures, except for trnS1(UCN) and trnS2(AGN) of G. parasita, and trnS2(AGN) of $N$. tetraclitophila. The structures of trnS2 of both species conform to the secondary structure achieved for known hoplonemertean mitogenomes, all lacking a DHU-arm which is replaced by a DHUloop [38,39]. trnS1 of G. parasita was inferred to be $59 \mathrm{bp}$, which makes it one of the shortest known tRNA genes of nemerteans. It has a 5-T DHU-loop instead of a DHU-arm. Uncanonical secondary structures of tRNA genes occur frequently during animal evolution [40].

\section{Non-coding regions}

There are a total of $265 \mathrm{bp}$ and $250 \mathrm{bp}$ non-coding nucleotides throughout the mitogenomes of G. parasita and $N$. tetraclitophila, accounting for $1.8 \%$ and $1.7 \%$ of the whole mitogenomes, respectively. The mNCRs are $120 \mathrm{bp}$ and $137 \mathrm{bp}$, respectively, both located between trn $W$ and trnS2. The A $+\mathrm{T}$ content $(70.8 \%$ and $73.7 \%)$ of both mNCRs is slightly higher compared with the whole coding strands, but not as high as that of the third codon position (Table 2). Besides poly-T/C/G stretches, the two mNCRs have a similarity of $33 \%$, which reflects a rapid evolutionary rate. Tandem repeats like those in Amphiporus formidabilis and Nipponnemertes punctatula [41] are not detected. In both, $N$. tetraclitophila and G. parasita, the mNCRs have the potential to fold into hairpin-like structures at the $5^{\prime}$ end (not shown), which might be involved in the beginning of replication and transcription [42]. The second longest mNCRs in the mitogenomes of $N$. 
Table 3 Partitioned Bremer support values for each gene partition on the combined tree nodes in Figure 4B

\begin{tabular}{llllllllllllll}
\hline Gene & A & B & C & D & E & F & G & H & I & J & K & Total BS & BS contribution (\%) \\
\hline 1st codon position & 181 & 86 & 1 & 13 & 43 & 16.5 & -2 & 26 & 30 & 2 & 15 & 411.5 & 33.7 \\
2nd codon position & 141 & 86 & 30.3 & 6 & 99 & 2.5 & 7 & 41 & 26 & 12 & 1 & 451.8 & 36.9 \\
rRNA & 98 & 19 & 7.7 & 0 & 40 & 8.5 & 18 & 22 & 5 & -5 & 3 & 216.2 & 17.7 \\
tRNA & 64 & 18 & 9 & 0 & 38 & 1.5 & -7 & 7 & 3 & 5 & 5 & 143.5 & 11.7 \\
Total & 484 & 209 & 48 & 19 & 220 & 29 & 16 & 96 & 64 & 14 & 24 & & \\
\hline
\end{tabular}

The partitioned Bremer support values for each node add up to the total Bremer support (BS) values.

tetraclitophila and G. parasita are both located between cox 1 and $\operatorname{trn} W(33 \mathrm{bp}$ and $28 \mathrm{bp}$, respectively), in agreement with other Monostilifera species [41].

\section{Phylogenetic analysis}

The concatenated datasets for amino acid and nucleotide sequences of the 13 protein-coding genes (excluding the 3rd codon position) yielded 3,056 and 6,721 aligned sites, respectively. The third dataset (comprising 8,962 nucleotide sites) was constructed by adding informative rRNA and tRNA gene sites to the above nucleotide dataset, which can help avoid directional migration resulting from only using protein-coding genes [43]. According to the Partitioned Bremer support (PBS) analysis [30], the rRNA and tRNA sequences contribute $17.7 \%$ and $11.7 \%$ (Table 3 ) of phylogenetic signal, respectively, making them promising for phylogenetic analysis.

Based on these three datasets, ML and BI analyses yielded identical tree topologies (Figure 4). All of them support the hypothesis that Hoplonemertea has a closer relationship with Heteronemertea than with Palaeonemertea, represented here by two Cephalothrix species that

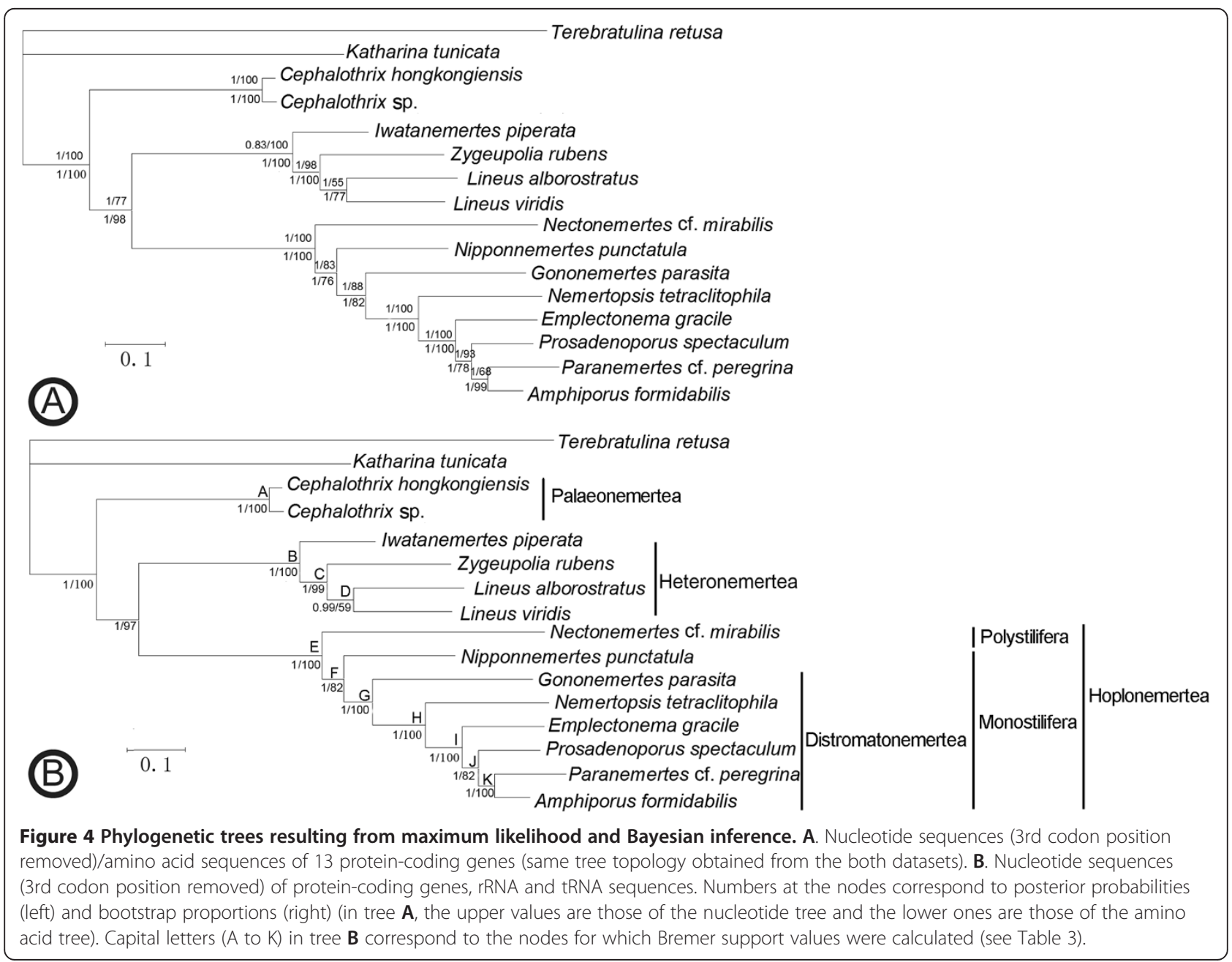


form the earliest divergent clade with high bootstrap values and posterior probabilities. As documented in previous studies [7,44], Polystilifera (Nectonemertes cf. mirabilis) is the sister group to Monostilifera; Nipponnemertes is sister to the other monostiliferans which make up the group Distromatonemertea [8]. The two present taxa, G. parasita and $N$. tetraclitophila, exhibit early divergent positions in the analyzed Distromatonemertea species. A recent analysis based on data of six genes also placed G. parasita in a basal Distromatonemertea clade containing mostly symbiotic and terrestrial species [9], whereas it was placed at a different position in the phylogenetic analysis of cox 1 and 18S rRNA sequences [45]. No similar species of the genus Nemertopsis have been studied in previous phylogenetic analyses. The position of the congeneric free-living species, Nemertopsis bivittata, was more or less different in previous analyses $[8,9]$ and seems to be different from the placement of $N$. tetraclitophila in the present study, which calls for further studies about the interrelationships within the genus Nemertopsis.

\section{Conclusions}

The complete mitochondrial genomes of Gononemertes parasita and Nemertopsis tetraclitophila, both of which possess some morphological characteristics adaptive to their lifestyle, are $14742 \mathrm{bp}$ and $14597 \mathrm{bp}$, respectively. They are identical to the previously published mitogenomes of free-living hoplonemerteans in gene content and gene order, and have similar patterns in nucleotide richness and skewness. The length of whole genomes, as well as protein-coding genes and ribosomal RNA genes, is relatively conservative within Distromatonemertea and shorter (with the exception of the rrnS of G. parasita) than that of the other nemerteans. As in other hoplonemerteans, the coding strands of the present two mitogenomes bear some poly- $T$ stretches; the tRNA genes usually exhibit cloverleaf-like structure except for trnS; the major non-coding regions exhibit AT-rich and hairpin-like structures that may be involved in transcription and replication. Some differences are found between the present mitogenomes and other hoplonemertean mitogenomes. For example, in G. parasita the mNCR is biased toward $\mathrm{T}$ and $\mathrm{C}$ (contrary to that in other hoplonemerteans) and the $\mathrm{rrnS}$ gene has a unique 58-bp insertion at $5^{\prime}$ end, and in N. tetraclitophila the nad3 gene starts with the ATT codon (ATG in other hoplonemerteans). However, we cannot conclude that these differences are related to their special lifestyle, because similar variations may also exist among free-living nemerteans and available mitogenomic data of nemerteans are stilled limited. Phylogenetic analyses show that both G. parasita and $N$. tetraclitophila are early divergent within the analyzed Distromatonemertea species.

\section{Additional files}

Additional file 1: Table S1. PCR primers used to amplify the mitochondrial genomes of Gononemertes parasita and Nemertopsis tetraclitophila.

Additional file 2: Table S2. Percentage of codon usage and relative synonymous codon usage (RSCU) of the 13 protein-coding genes in the mitogenomes of Gononemertes parasita (Gp) and Nemertopsis tetraclitophila $(\mathrm{Nt})$.

\section{Abbreviations}

atp6 and atp8: ATP synthase subunits 6 and 8; cytb: Cytochrome b; cox 1-3: Cytochrome $c$ oxidase subunits I-III; nad1-6 and nad4L: NADH dehydrogenase subunits 1-6 and $4 \mathrm{~L} ; \mathrm{rrnL}$ and $r r n S$ : The large and small subunits of ribosomal RNA; trnX: Transfer RNA molecules with the one-letter code of corresponding amino acid; DHU: Dihydrouridine; mNCR: Major non-coding region;

PCR: Polymerase chain reaction; bp: Base pair.

\section{Competing interests}

The authors declare that they have no competing interests.

\section{Authors' contributions}

S-CS conceived and designed the study. W-YS and D-LX performed the experiments. W-YS, D-LX and WS analyzed the data. MS, PS and S-CS collected and identified specimens. WY-S drafted the manuscript. S-C S, $\mathrm{H}-\mathrm{XC}$ and PS revised the manuscript. All authors read and approved the final manuscript.

\section{Acknowledgements}

This work is supported by the National Natural Science Foundation of China (31172046; 30970333). We are grateful to Mr. Hai-Lin Shen for assistance in collecting specimens.

\section{Author details}

${ }^{1}$ Institute of Evolution \& Marine Biodiversity, Ocean University of China, 5 Yushan Road, Qingdao 266003, China. ²Department of Biological and Environmental Sciences, University of Gothenburg, PO Box 463, SE-405 30 Gothenburg, Sweden. ${ }^{3}$ Key Laboratory of Marine Bio-resource Sustainable Utilization (LMB), South China Sea Institute of Oceanology, Chinese Academy of Sciences, 164 West Xingang Road, Guangzhou 510301, China. ${ }^{4}$ Swedish Species Information Centre, Swedish University of Agricultural Sciences, Box 7007, SE 75007 Uppsala, Sweden.

Received: 20 April 2014 Accepted: 14 June 2014

Published: 19 June 2014

\section{References}

1. Kajihara H, Chernyshev AV, Sun S-C, Sundberg P, Crandall FB: Checklist of nemertean genera and species published between 1995-2007. Species Div 2008, 13:245-274.

2. Turbeville JM, Field KG, Raff RA: Phylogenetic position of phylum Nemertini, inferred from 18S rRNA sequences: molecular data as a test of morphological character homology. Mol Biol Evol 1992, 9:235-249.

3. Passamaneck Y, Halanych KM: Lophotrochozoan phylogeny assessed with LSU and SSU data: evidence of lophophorate polyphyly. Mol Phylogenet Evol 2006, 40:20-28.

4. Dunn CW, Hejnol A, Matus DQ, Pang K, Browne WE, Smith SA, Seaver E, Rouse GW, Obst M, Edgecombe GD, Sørensen MV, Haddock SH, SchmidtRhaesa A, Okusu A, Kristensen RM, Wheeler WC, Martindale MQ, Giribet G: Broad phylogenomic sampling improves resolution of the animal tree of life. Nature 2008, 452:745-749.

5. Podsiadlowski L, Braband A, Struck TH, von Dohren J, Bartolomaeus T: Phylogeny and mitochondrial gene order variation in Lophotrochozoa in the light of new mitogenomic data from Nemertea. BMC Genomics 2009, 10:364.

6. Turbeville JM: An ultrastructural analysis of coelomogenesis in the hoplonemertine Prosorhochmus americanus and the polychaete Magelona sp. J Morphol 1986, 187:51-60.

7. Sundberg P, Turbeville JM, Lindh S: Phylogenetic relationships among higher Nemertean (Nemertea) Taxa inferred from 18S rDNA sequences. Mol Phylogenet Evol 2001, 20:327-334 
8. Thollesson M, Norenburg JL: Ribbon worm relationships: a phylogeny of the phylum Nemertea. Proc Biol Sci 2003, 270:407-415.

9. Andrade SCS, Strand M, Schwartz M, Chen HX, Kajihara H, Von Döhren J, Sun SC, Junoy J, Thiele M, Norenburg JL, Turbeville JM, Giribet G, Sundberg P. Disentangling ribbon worm relationships: multi-locus analysis supports traditional classification of the phylum Nemertea. Cladistics 2012, 28:141-159.

10. Strand M, Samuelsson H, Sundberg P: Nationalnyckeln till Sveriges flora och fauna. Stjärnmaskar - slemmaskar. Sipuncula - Nemertea. Uppsala: ArtDatabanken, SLU; 2010.

11. Gibson R: The macrobenthic nemertean fauna of Hong Kong. In Proceedings of the Second International Marine Biological Workshop: the Marine Flora and Fauna of Hong Kong and Southern China, 1986. Volume 1. Edited by Morton B. Hong Kong: Hong Kong University Press; 1990:33-212

12. Bergendal D: Über ein Paar sehr eigenthümliche nordische Nemertinen. Zoologischer Anzeiger 1900, 23:313-328.

13. Roe P: Ecological implications of the reproductive biology of symbiotic nemerteans. Hydrobiologia 1988, 156:13-22.

14. Lowe TM, Eddy SR: tRNAscan-SE: a program for improved detection of transfer RNA genes in genomic sequence. Nucleic Acids Res 1997, 25:955-964

15. Denman RB: Using RNAFOLD to predict the activity of small catalytic RNAs. Biotechniques 1993, 15:1090-1095.

16. Grant JR, Stothard P: The CGView server: a comparative genomics tool for circular genomes. Nucleic Acids Res 2008, 36:W181-W184.

17. Xia X: DAMBE5: a comprehensive software package for data analysis in molecular biology and evolution. Mol Biol Evol 2013, 30:1720-1728.

18. Thompson JD, Gibson TJ, Plewniak F, Jeanmougin F, Higgins DG: The CLUSTAL_X windows interface: flexible strategies for multiple sequence alignment aided by quality analysis tools. Nucleic Acids Res 1997, 25:4876-4882.

19. Tamura K, Peterson D, Peterson N, Stecher G, Nei M, Kumar S: MEGA5: molecular evolutionary genetics analysis using maximum likelihood, evolutionary distance, and maximum parsimony methods. Mol Biol Evol 2011, 28:2731-2739.

20. Golombek A, Tobergte S, Nesnidal MP, Purschke G, Struck TH: Mitochondrial genomes to the rescue - diurodrilidae in the myzostomid trap. Mol Phylogenet Evol 2013, 68:312-326.

21. Stöger I, Schrodl M: Mitogenomics does not resolve deep molluscan relationships (yet?). Mol Phylogenet Evol 2013, 69:376-392.

22. Talavera G, Castresana J: Improvement of phylogenies after removing divergent and ambiguously aligned blocks from protein sequence alignments. Syst Biol 2007, 56:564-577.

23. Posada D, Crandall KA: MODELTEST: testing the model of DNA substitution. Bioinformatics 1998, 14:817-818.

24. Nylander JAA: MrModeltest v2. Program distributed by the author. Evolutionary Biology Centre, Uppsala University; 2004 [http://www.abc.se/]

25. Abascal F, Zardoya R, Posada D: ProtTest: selection of best-fit models of protein evolution. Bioinformatics 2005, 21:2104-2105.

26. Guindon S, Dufayard JF, Lefort V, Anisimova M, Hordijk W, Gascuel O: New algorithms and methods to estimate maximum-likelihood phylogenies: assessing the performance of PhyML 3.0. Syst Biol 2010, 59:307-321.

27. Ronquist F, Huelsenbeck JP: MrBayes 3: Bayesian phylogenetic inference under mixed models. Bioinformatics 2003, 19:1572-1574.

28. Swofford DL: PAUP* - Phylogenetic Analysis Using Parsimony (*and Other Methods). Ver. 4.0. [Computer software and manual]. Sunderland, MA: Sinauer Associates. In Book PAUP* - Phylogenetic Analysis Using Parsimony (*and Other Methods). Ver. 4.0. [Computer software and manual]. Sunderland, MA: Sinauer Associates; 1999.

29. TreeRot version 3. [http://people.bu.edu/msoren/TreeRot.html].

30. Bremer $\mathrm{K}$ : The limits of amino acid sequence data in angiosperm phylogenetic reconstruction. Evolution 1988, 42:795-803.

31. Bremer K: Branch support and tree stability. Cladistics 1994, 10:295-304.

32. Hassanin A, Leger N, Deutsch J: Evidence for multiple reversals of asymmetric mutational constraints during the evolution of the mitochondrial genome of metazoa, and consequences for phylogenetic inferences. Syst Biol 2005, 54:277-298.

33. Riepsamen AH, Gibson T, Rowe J, Chitwood DJ, Subbotin SA, Dowton M: Poly $(T)$ variation in heteroderid nematode mitochondrial genomes is predominantly an artefact of amplification. J Mol Evol 2011, 72:182-192.

34. Gibson T, Farrugia D, Barrett J, Chitwood DJ, Rowe J, Subbotin S, Dowton M: The mitochondrial genome of the soybean cyst nematode, Heterodera glycines. Genome 2011, 54:565-574.
35. Nesnidal MP, Helmkampf M, Bruchhaus I, Hausdorf B: The complete mitochondrial genome of Flustra foliacea (Ectoprocta, Cheilostomata) compositional bias affects phylogenetic analyses of lophotrochozoan relationships. BMC Genomics 2011, 12:572.

36. Ojala D, Montoya J, Attardi G: tRNA punctuation model of RNA processing in human mitochondria. Nature 1981, 290:470-474.

37. McMahon DP, Hayward A, Kathirithamby J: The mitochondrial genome of the 'twisted-wing parasite' Mengenilla australiensis (Insecta, Strepsiptera): a comparative study. BMC Genomics 2009, 10:603.

38. Chen HX, Sun SC, Sundberg P, Ren WC, Norenburg JL: A comparative study of nemertean complete mitochondrial genomes, including two new ones for Nectonemertes cf. mirabilis and Zygeupolia rubens, may elucidate the fundamental pattern for the phylum Nemertea. BMC Genomics 2012, 13:139.

39. Chen HX, Sundberg P, Wu HY, Sun SC: The mitochondrial genomes of two nemerteans, Cephalothrix sp. (Nemertea: Palaeonemertea) and Paranemertes cf. peregrina (Nemertea: Hoplonemertea). Mol Biol Rep 2011, 38:4509-4525.

40. Gasser RB, Jabbar A, Mohandas N, Hoglund J, Hall RS, Littlewood DT, Jex AR: Assessment of the genetic relationship between Dictyocaulus species from Bos taurus and Cervus elaphus using complete mitochondrial genomic datasets. Parasit Vectors 2012, 5:241.

41. Sun WY, Sun SC: A description of the complete mitochondrial genomes of Amphiporus formidabilis. Mol Biol Rep, in press: Prosadenoporus spectaculum and Nipponnemertes punctatula (Nemertea: Hoplonemertea: Monostilifera); doi:10.1007/s11033-014-3438-5.

42. Arnason E, Rand DM: Heteroplasmy of short tandem repeats in mitochondrial DNA of Atlantic cod, Gadus morhua. Genetics 1992 132:211-220.

43. Kumazawa $Y$, Nishida M: Sequence evolution of mitochondrial tRNA genes and deep-branch animal phylogenetics. J Mol Evol 1993, 37:380-398.

44. Sundberg P, Chernyshev AV, Kajihara H, Kanneby T, Strand M: Charactermatrix based descriptions of two new nemertean (Nemertea) species. Zool J Linn Soc 2009, 157:264-294.

45. Junoy J, Andrade SCS, Giribet G: Phylogenetic placement of a new hoplonemertean species commensal on ascidians. Invertebr Syst 2010, 24:616-629.

doi:10.1186/1756-3305-7-273

Cite this article as: Sun et al:: Complete mitochondrial genome sequences of two parasitic/commensal nemerteans, Gononemertes parasita and Nemertopsis tetraclitophila (Nemertea: Hoplonemertea). Parasites \& Vectors 2014 7:273.

\section{Submit your next manuscript to BioMed Central and take full advantage of:}

- Convenient online submission

- Thorough peer review

- No space constraints or color figure charges

- Immediate publication on acceptance

- Inclusion in PubMed, CAS, Scopus and Google Scholar

- Research which is freely available for redistribution 